\title{
Article
}

\section{The Endophytic Fungus Piriformospora Indica-Assisted Alleviation of Cadmium in Tobacco}

\author{
Zhenzhu Su ${ }^{1}$, Yulan Zeng ${ }^{1}$, Xiaoli Li ${ }^{2}$, Anand Babu Perumal ${ }^{2}$, Jianan Zhu ${ }^{1}$, Xuanjun Lu ${ }^{1}$, Mengdi Dai ${ }^{3}$, \\ Xiaohong Liu $^{1}$ and Fucheng Lin $1,3, *$ \\ 1 Institute of Biotechnology, Zhejiang University, Hangzhou 310058, China; zzsu@zju.edu.cn (Z.S.); \\ 12016090@zju.edu.cn (Y.Z.); 18846921667@163.com (J.Z.); luxuanjun595@163.com (X.L.); \\ xhliu@zju.edu.cn (X.L.) \\ 2 College of Biosystems Engineering and Food Science, Zhejiang University, Hangzhou 310058, China; \\ xiaolili@zju.edu.cn (X.L.); anandbabu@zju.edu.cn (A.B.P.) \\ 3 State Key Laboratory for Managing Biotic and Chemical Treats to the Quality and Safety of Agro-Products, \\ Institute of Plant Protection and Microbiology, Zhejiang Academy of Agricultural Sciences, \\ Hangzhou 310021, China; 11616058@zju.edu.cn \\ * Correspondence: fuchenglin@zju.edu.cn; Tel.: +86-571-8640-4007
}

check for updates

Citation: Su, Z.; Zeng, Y.; Li, X.; Perumal, A.B.; Zhu, J.; Lu, X.; Dai, M.; Liu, X.; Lin, F. The Endophytic Fungus Piriformospora Indica-Assisted Alleviation of Cadmium in Tobacco. J. Fungi 2021, 7, 675. https://doi.org/10.3390/ jof7080675

Academic Editors: Nuria Ferrol and Laurent Dufosse

Received: 6 July 2021

Accepted: 18 August 2021

Published: 20 August 2021

Publisher's Note: MDPI stays neutral with regard to jurisdictional claims in published maps and institutional affiliations.

Copyright: (C) 2021 by the authors. Licensee MDPI, Basel, Switzerland. This article is an open access article distributed under the terms and conditions of the Creative Commons Attribution (CC BY) license (https:/ / creativecommons.org/licenses/by/ $4.0 /)$.

\begin{abstract}
Increasing evidence suggests that the endophytic fungus Piriformospora indica helps plants overcome various abiotic stresses, especially heavy metals. However, the mechanism of heavy metal tolerance has not yet been elucidated. Here, the role of $P$. indica in alleviating cadmium (Cd) toxicities in tobacco was investigated. It was found that $P$. indica improved $\mathrm{Cd}$ tolerance to tobacco, increasing $\mathrm{Cd}$ accumulation in roots but decreasing $\mathrm{Cd}$ accumulation in leaves. The colonization of $P$. indica altered the subcellular repartition of $\mathrm{Cd}$, increasing the $\mathrm{Cd}$ proportion in cell walls while reducing the $\mathrm{Cd}$ proportion in membrane/organelle and soluble fractions. During Cd stress, P. indica significantly enhanced the peroxidase (POD) activity and glutathione (GSH) content in tobacco. The spatial distribution of GSH was further visualized by Raman spectroscopy, showing that GSH was distributed in the cortex of $P$. indica-inoculated roots while in the epidermis of the control roots. A LC-MS/MS-based label-free quantitative technique evaluated the differential proteomics of $P$. indica treatment vs. control plants under Cd stress. The expressions of peroxidase, glutathione synthase, and photosynthesis-related proteins were significantly upregulated. This study provided extensive evidence for how $P$. indica enhances $\mathrm{Cd}$ tolerance in tobacco at physiological, cytological, and protein levels.
\end{abstract}

Keywords: endophytic fungi; Piriformospora indica; cadmium; tolerance; proteomics; glutathione

\section{Introduction}

Over the past few decades, increased anthropogenic activities, rapid industrialization, and modern agricultural practices have aggravated heavy metal pollution in the environment [1]. Large farmland areas have been contaminated with heavy metals due to the extensive use of pesticides, fertilizers, and contaminated water irrigation, posing a severe threat to crop safety and human health [2,3]. Cadmium (Cd) is one of the most toxic heavy metals in agricultural fields and raised various harmful effects on crop plants such as a decrease in yield, slow germination, leaf chlorosis, necrosis, etc. [4-6].

The application of heavy metal hyperaccumulators for phytoremediation is a sustainable solution. Various Cd hyperaccumulator plant species have been extensively investigated $[7,8]$. However, the hyperaccumulators have many disadvantages, such as low growth rate, small biomass, low commercial availability [9]. Therefore, some crop species with high commercial value, fast growth rate, high yield, and medium-heavy metal adsorption capacity provide new opportunities for hyperaccumulators. Tobacco (Nicotiana tabacum L.) is a well-known economic crop around the world. It has been applied 
as Cd phytoremediators for decades [10-14]. However, the Cd tolerance of tobacco is always limited to $\mathrm{Cd}$ concentration, Nicotiana varieties, exposure time, etc. [15]. Therefore, it is necessary to develop an innovative strategy that improves tobacco's phytoextraction capacity and ensures edible leaves' food safety.

Combing plants and their associated microorganisms to eliminate contaminants provides a cost-effective, in-situ, and promising technology [16]. The root-associated microorganisms, such as mycorrhizal fungi and endophytic fungi, can remove, inactivate, or degrade harmful environmental contaminants [17-19]. Endophytic fungi are the essential components of root microflora in the metal-contaminated ecosystem [20]. They possess various degradation pathways, such as metal sequestration and chelation systems, by which they increase host heavy metal tolerance and assist the host survival in contaminated soils [21-23]. During symbiosis, endophytic fungi either directly induce resistance of the host plants to deal with heavy metal toxicity or indirectly improve tolerance by improving water and mineral nutrient uptake in plants, increasing shoot biomass, causing modification in the root morphology. Endophytic fungi-assisted phytoremediation is a costeffective and environment-friendly strategy [24]. Piriformospora indica, a well-studied rootcolonizing endophytic fungus, was isolated from the woody shrubs Prosopsis juliflora and Zizyphus nummularia growing in the Indian Thar desert [25]. It was classified in Hymenomycetes, Basidiomycota [25], and can colonize many plants. P. indica confers various benefits to host plants, such as growth promotion, seed yield increase, and enhanced resistance/tolerance to biotic and abiotic stresses [26-29]. P. indica could improve the tolerance of host plants to heavy metals $[30,31]$. It possesses an excellent capacity to immobilize heavy metals in plant roots, which can be very promising in phytoremediation [30].

Although it has been recognized that $P$. indica plays a vital role in plant tolerance to heavy metals, the underlying mechanism remains obscure. This work aims to assess whether $P$. indica has the potential to confer Cd tolerance to tobacco cultivars. In addition, the effect of $P$. indica on $\mathrm{Cd}$ tissue accumulation and subcellular repartition in tobacco was investigated. Furthermore, we applied label-free quantitative proteomics to explore the underlying mechanism of $P$. indica-induced $\mathrm{Cd}$ tolerance in tobacco. Our findings will elucidate the mutualistic mechanism between tobacco and P. indica under $\mathrm{Cd}$ stress.

\section{Materials and Methods}

\subsection{Co-Cultivation of P. indica and Tobacco}

Co-culturing P. indica and tobacco assayed the effect of P. indica on the Cd tolerance of tobacco in tissue culture bottles. Tobacco seeds were surface-sterilized in $1 \%$ sodium hypochlorite solution for $10 \mathrm{~min}$, rinsed in sterile water. They were then planted in solid Murashige \& Skoog medium and inoculated with $P$. indica strain plugs (one seed, one fungal plug per bottle). The plants inoculated with sterile plugs were the control. The plants were kept with a $16 \mathrm{~h} \mathrm{light} / 8 \mathrm{~h}$ dark photoperiod at $24 / 22{ }^{\circ} \mathrm{C}$ for 20 days. Then, all plants were transplanted and underwent hydroponic culture. The liquid medium contained 0 and $2 \mathrm{mg} \cdot \mathrm{L}^{-1} \mathrm{Cd}$, respectively. Four treatment groups were designed: the control (Con), P. indica-treated (Pi), Cd-treated (HM), and P. indica- and Cd-treated (PH) groups. Each group contained 30 plants. After treatment for 30 days, the $\mathrm{Cd}$ content and growth parameters of the tobacco plants were measured. In addition, the chlorophyll content was measured by a SPAD-502 chlorophyll meter (Konica-Minolta, Osaka, Japan).

\subsection{Endophytic Fungus, Cd Treatment, Microscopy}

We evaluated the $\mathrm{Cd}$ tolerance of $P$. indica by inoculating a fungal plug onto a piece of sterilized glass paper placing on potato dextrose agar (PDA) containing $\mathrm{Cd}$ at a series of concentrations ranging from 0 to $2.5 \mathrm{mg} \cdot \mathrm{L}^{-1}$. The fungus was incubated at $25{ }^{\circ} \mathrm{C}$ for 10 days in darkness. The MIC value was used to evaluate the tolerance of $P$. indica to $\mathrm{Cd}^{2+}$.

The Cd-treated fungal sample was desorbed in $20 \mathrm{mM} \mathrm{Na} 2$ EDTA for $15 \mathrm{~min}$, washed with deionized water 3 times, and stained with Leadmium Green AM dye (Molecular Probes, Invitrogen, Carlsbad, CA, USA) in the dark. Then, the sample was stained by 
lipophilic endocytic dye FM4-64 for 30 min. Finally, distilled water was used to wash the samples 3 times to remove the excess fluorescent dye. The $\mathrm{Cd}$-specific fluorescent probe was detected at $515 \mathrm{~nm}$ using an excitation wavelength of $488 \mathrm{~nm}$. The fluorescence of FM4-64 was detected at $640-700 \mathrm{~nm}$ using an excitation wavelength of $514 \mathrm{~nm}$ under a LSM780 laser scanning confocal microscope.

\subsection{Determination of Metal Contents and Electron Microscopy}

The metal content was analyzed by ICP-MS (iCAP RQ, Thermofisher Scientific, Foster, CA, USA). For transmission electron microscopy (TEM), the samples were examined in the Hitachi H-7650 instrument at $60-80 \mathrm{kV}$. The samples were observed for scanning electron microscopy (SEM) under a ZEISS Gemini SEM 300 (Carl Zeiss, Oberkochen, Baden-Württemberg, Germany).

The root samples of HM and PH groups were collected, embedded in resin, then sliced into $5 \mu \mathrm{m}$ slices by a slicer (LKB Bromma ultratome pyramitome 11800, Stockholm, Sweden). Subsequently, the ultrathin section was map-scanned by a micro-confocal Raman spectrometer (inVia-Reflex 532/XYZ, Renishaw, London, UK).

\subsection{Distribution of Cadmium in Subcellular Fractions of Leaves and Roots}

Subcellular tissue fractions were extracted according to the method described by $\mathrm{Wu}$ et al. [32]. Firstly, $0.5 \mathrm{~g}$ of the tissues were homogenized in cold extracting buffer $(50 \mathrm{mM}$ Tris- $\mathrm{HCl}, 1.0 \mathrm{mM}$ DTE $\left(\mathrm{C}_{4} \mathrm{H}_{10} \mathrm{O}_{2} \mathrm{~S}_{2}\right), 250 \mathrm{mM}$ sucrose, $5.0 \mathrm{mM}$ ascorbic acid, and $1.0 \%$ w:v Polyclar AT PVPP ( $\mathrm{pH}=7.5)$ with a chilled mortar and pestle. The homogenate was then filtered by a nylon cloth $(240 \mu \mathrm{m})$. The cell wall residue on the nylon cloth was washed three times with the buffer. The filtrate was then centrifuged at $2500 \times g$ for $20 \mathrm{~min}$ (for root filtrate), or $1500 \times g$ for $10 \mathrm{~min}$ (leaf filtrate). In addition, the pellet obtained was the chloroplast/trophoplast fraction for leaf and root, respectively. Then, the supernatant was centrifuged at $5000 \times g$ for $35 \mathrm{~min}$, and the pellet was regarded as the membrane and organelle fraction, while the supernatant represented the soluble fraction. All steps were performed at $4{ }^{\circ} \mathrm{C}$. Cd contents of all subcellular fractions were determined via ICP-MS described above.

\subsection{Determination of Antioxidant Substances}

The root samples of tobacco plants that underwent hydroponic culture for 30 days were collected for analysis. The activities of the antioxidant enzyme POD and the level of GSH were assessed. According to the manufacturer's protocols, all assays were conducted using commercial chemical assay kits (Nanjing Jiancheng Bioengineering Institute, Nanjing, China), and each sample was examined in triplicate.

\subsection{Protein Preparation, Mass Spectrometry, Identification, and Quantification}

Total proteins of $300 \mathrm{mg}$ of fresh roots were extracted by a modified trichloroacetic acid (TCA)-acetone-phenol method [33]. In brief, $100 \mu \mathrm{g}$ of the protein were digested using the filter-aided sample preparation (FASP) method. The peptides were then desalted by ZIPTIP C18 spin tips (Millipore, Merck KGaA, Darmstadt, Germany). A liquid chromatography/mass spectrometry (LC/MS) system analyzed the tryptic peptides [34-36].

MaxQuant_1.5.2.8 analyzed raw MS files. The databases of P. indica (proteome ID: UP000007148) and tobacco proteins were interrogated. A pairwise comparison of HM and $\mathrm{PH}$ samples in triplicate was performed to explore the similarities and differences. We used label-free quantification to identify differentially expressed proteins (DEPs) with a $95 \%$ confidence level ( $p$-value $\leq 0.05)$, and fold change $>2$. ANOVA calculated the significance. Mapping and annotation were performed with Blast2GO (http:/ / www.ebi. ac.uk/interpro/InterProScanv5.22-61.0 (accessed on 23 January 2017). DEPs mapping and pathway analysis were performed through the KEGG pathway database (http:// www.genome.jp/kegg/Release85.0) (accessed on 1 January 2018). The StringDB protein 
interaction database (http:/ / string-db.org/v.10) (accessed on 16 April 2016 to 14 May 2017) was used for the identified protein-protein interaction (PPI) analysis.

\subsection{Statistical Analysis}

Each experiment was performed in triplicate. The data were statistically analyzed using SPSS version 16.0 software (SPSS Inc., Chicago, IL, USA) and are presented as the mean \pm standard deviation (SD). Graphs were created using GraphPad Prism 8.

\section{Results}

\subsection{P. indica Improves the $C d$ Tolerance of Tobacco}

The presence of $P$. indica significantly promoted plant growth. Compared with the control group, the growth parameters of $P$. indica-colonized seedlings, such as the shoot height, shoot fresh weight, root length, fresh root weight, and total dry weight, were enhanced by $48.54 \%, 103.63 \%, 139.16 \%, 134.77 \%$, and $120.39 \%$, respectively $(p<0.01)$ (Figure $1 \mathrm{~A}-\mathrm{F})$. Cd treatment resulted in tobacco seedlings growing slowly and turning yellow (Figure 1A). However, the root colonization of $P$. indica alleviated these toxicity symptoms. The $P$. indicacolonized tobacco seedlings grew normally without any apparent dwarfing or chlorosis (Figure 1A), showing a higher level in the shoot height (173.82\%), shoot fresh weight $(227.38 \%)$, root length $(228.13 \%)$, root biomass $(228.11 \%)$, and chlorophyll content $(59.4 \%)$ than Cd-treated plants $(p<0.01$ ) (Figure 1B-G). These results suggested that $P$. indica conferred an improved $\mathrm{Cd}$ tolerance to tobacco.
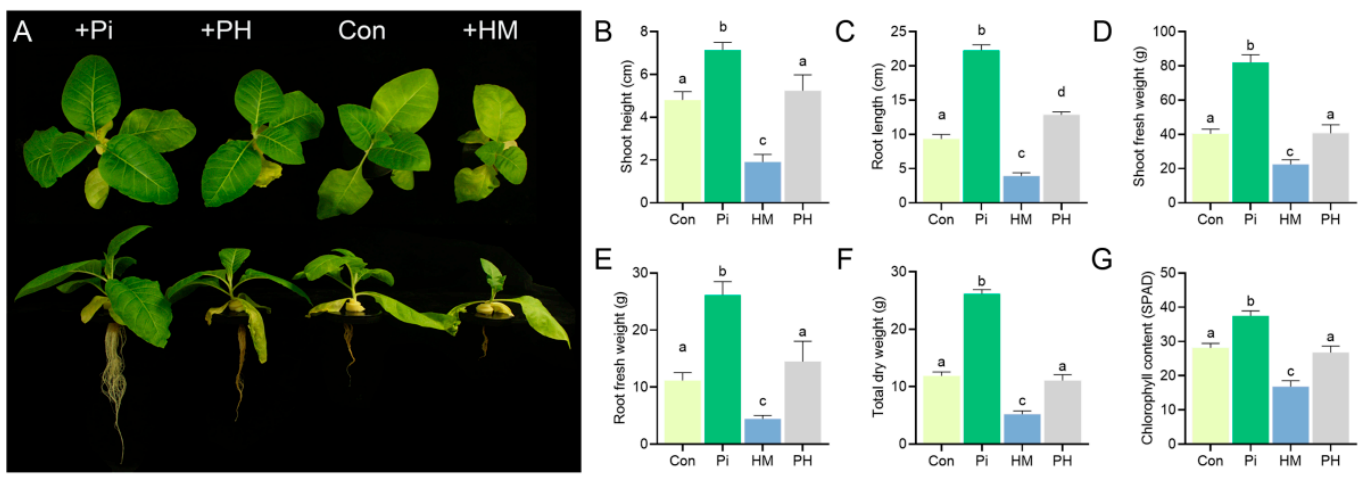

Figure 1. Cd tolerance of tobacco conferred by P. indica. (A) Effect of $P$. indica on the growth of tobacco seedlings in the presence of Cd. Control: non-treated, + F: P. indica-inoculated, $+\mathrm{Cd}$ : Cd-treated $(5 \mu \mathrm{M}),+\mathrm{CdF}$ : both $P$. indica- and Cd-treated $(5 \mu \mathrm{M})$. The same abbreviations are used below. (B-G) Effects of $P$. indica on the growth parameters of tobacco seedlings under Cd stress. The bars represent the means \pm SDs, $n=9$. Significant differences (one-way ANOVA): lowercase letters $(\mathrm{a}-\mathrm{c})$ mean $p<0.05$.

\subsection{P. indica Alleviates the Root Damage Caused by $\mathrm{Cd}$}

SEM observations showed that the root surface of the control seedlings was intact, while the root surface of the Cd-treated group was severely damaged. In the natural condition, P. indica formed many running hyphae and chlamydospores wrapping around the root surface. The hyphae grew longitudinally and were arranged neatly, whereas, under Cd stress, fungal hyphae became twisted and deformed (Figure 2A).

The semithin section showed that $\mathrm{Cd}$ stress resulted in severe shrinkage and deformation of root epidermal and cortical cells. However, $P$. indica colonization eliminated these toxic symptoms caused by $\mathrm{Cd}$, arranging the root cells to line up tightly (Figure 2B).

Ultrastructural observations further revealed that $\mathrm{Cd}$ exposure resulted in severe plasmolysis in root cells (Figure 2C). However, the presence of $P$. indica eliminated this plasmolysis, with the cells showing smooth and continuous cell membranes and a granular cytoplasm (Figure 2C). 


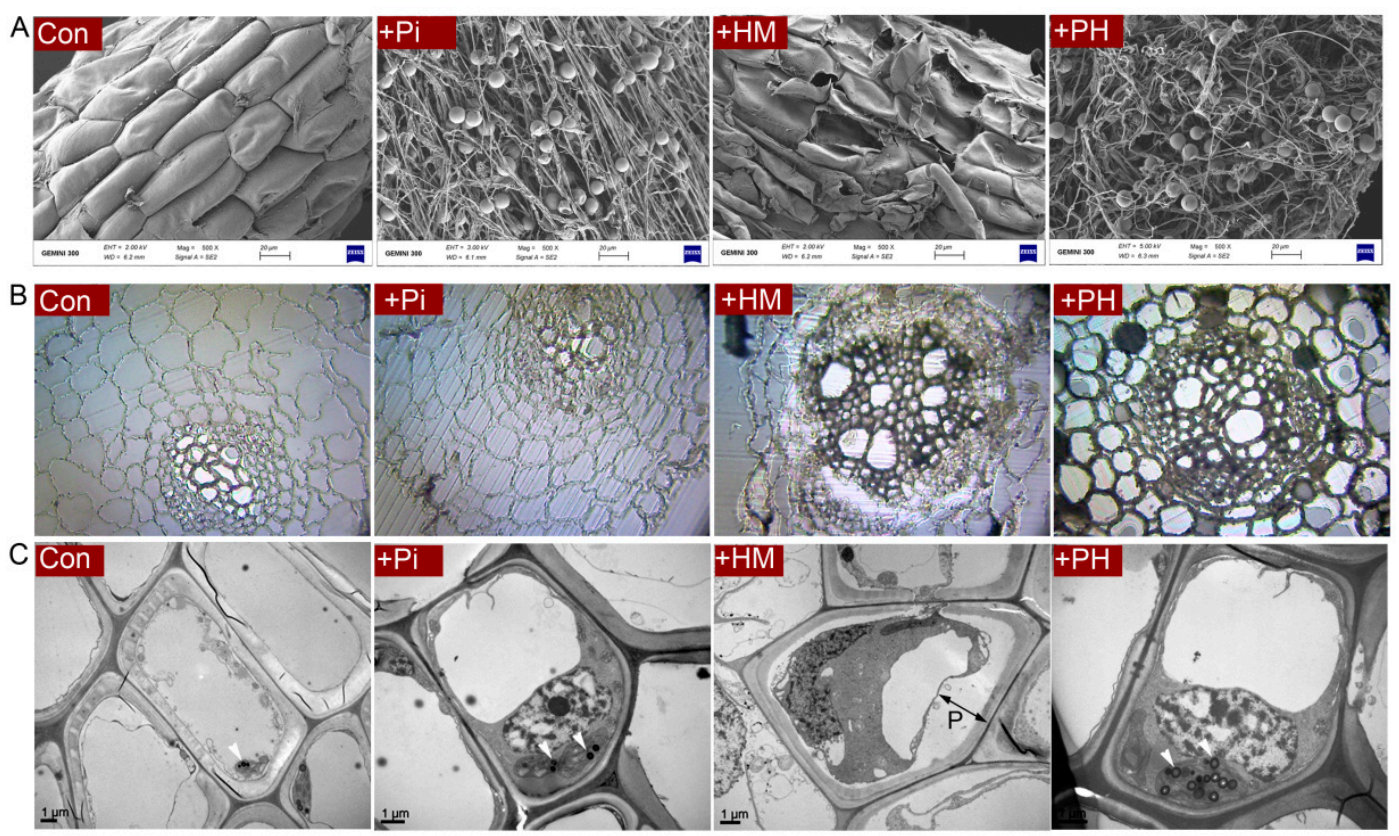

Figure 2. (A) Scanning electron microscopy of the root surface. (B) Observation of semithin section of root cross-section. (C) Ultrastructure of root cells under transmission electron microscopy. $p$ means plasmolysis. Arrowheads mean plastoglobulis.

\subsection{Effect of P. indica on Cd Accumulation, Subcellular Distribution, and Antioxidant Level}

The improved $\mathrm{Cd}$ tolerance of tobacco conferred by $P$. indica prompted us to investigate whether the accumulation and distribution of $\mathrm{Cd}$ in tobacco were altered. It was found that the presence of $P$. indica significantly increased the $\mathrm{Cd}$ concentration in roots (by $108.73 \%$ ) and decreased the $\mathrm{Cd}$ concentration in leaves (by $47.42 \%$ ) compared to the noninoculated tobacco under $\mathrm{Cd}$ treatment $(p<0.0001$ ) (Figure 3A). The majority of the $\mathrm{Cd}$ was accumulated in the leaves of HM group plants. However, the colonization of $P$. indica altered this accumulation pattern, accumulating most $\mathrm{Cd}$ in the roots of $\mathrm{PH}$ treatment plants while reducing $\mathrm{Cd}$ accumulation in leaves (Figure 3A). The subcellular repartition of $\mathrm{Cd}$ in tobacco roots and leaves was investigated for $\mathrm{HM}$ and $\mathrm{PH}$ treatments (Table 1, Figure 3B). Across all treatments, the accumulation of $\mathrm{Cd}$ in the cell walls was the highest in both leaves and roots, followed by the soluble fractions, and the accumulation of $\mathrm{Cd}$ in the membrane/organelle fraction was the lowest (Figure 3B). Notably, the Cd concentrations in all subcellular components of the P. indica-inoculated plant roots were significantly higher than those in the non-inoculated plants. On the contrary, the Cd concentration in each component of the P. indica-inoculated plant leaves significantly decreased compared to the non-inoculated plant (Table 1).

Interestingly, P. indica colonization increased Cd accumulation in the cell wall, which resulted in a significant decrease in $\mathrm{Cd}$ accumulation in membrane/organelle and soluble fractions in both leaves and roots (Figure 3B). For instance, under Cd stress, the proportion of $\mathrm{Cd}$ accumulation in the cell wall of roots and leaves of non-inoculated tobacco was $38.43 \%$ and $46.55 \%$, respectively. In comparison, the proportion of $\mathrm{Cd}$ accumulation in the cell wall of roots and leaves in P. indica-inoculated plants was $52.23 \%$ and $57.11 \%$, respectively (Figure 3B). The proportion of soluble $\mathrm{Cd}$ in $\mathrm{P}$. indica-colonized roots decreased from $37.58 \%$ to $22.28 \%$ and from $33.83 \%$ to $31.25 \%$ in leaves. Similarly, the proportion of $\mathrm{Cd}$ accumulation in membrane/organelle components decreased from $4.74 \%$ to $2.89 \%$ in roots and from $4.60 \%$ to $3.29 \%$ in the leaves, respectively (Figure 3B). 


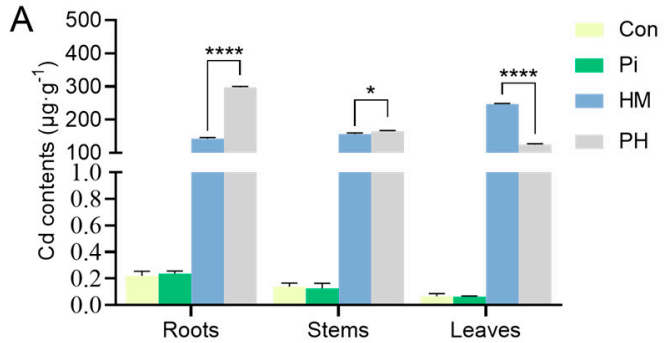

C

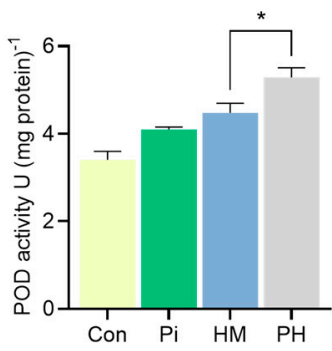

B

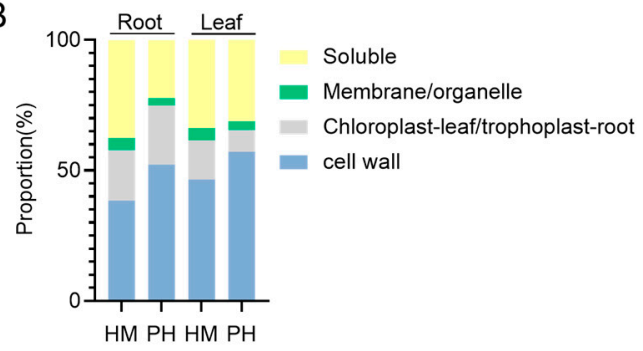

$\mathrm{D}$

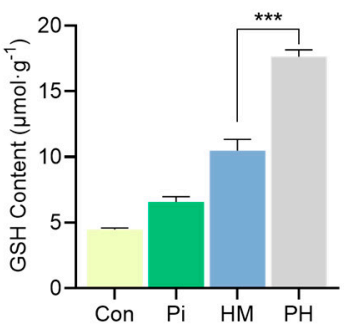

Figure 3. (A) Effect of $P$. indica on the spatial accumulation of $\mathrm{Cd}$ in different tissues of tobacco seedlings. The bars represent the means \pm SDs, $n=3$. Different letters on the bars mean significant differences at $p<0.001$ ( $t$-test). (B) The subcellular proportion of $\mathrm{Cd}$ in tobacco roots and leaves with $P$. indica inoculation or not. (C,D) The effect of $P$. indica on the antioxidant levels in tobacco under Cd stress. The bars represent the means $\pm \mathrm{SDs}, n=3$. Significant differences $\left(t\right.$-test): ${ }^{*}$ means $p<0.05$, *** means $p<0.001,{ }^{* * * *}$ means $p<0.0001$.

Table 1. Subcellular distribution of $\mathrm{Cd}$ in tobacco inoculated with $P$. indica (PH) or not (HM) under Cd stress.

\begin{tabular}{cccccc}
\hline \multirow{2}{*}{ Tissue } & \multirow{2}{*}{ Treatment } & \multicolumn{4}{c}{ Cd Concentrations in Each Cell Fraction $\left(\mu \mathrm{g} \cdot \mathbf{g}^{-\mathbf{1}}\right)$} \\
\cline { 3 - 6 } & & Cell Wall & Trophoplast/Chloroplast & Membrane/Organelle & Soluble \\
\cline { 3 - 6 } \multirow{2}{*}{ Root } & HM & $54.29 \pm 5.00$ & $27.20 \pm 0.71$ & $6.70 \pm 0.35$ & $53.10 \pm 1.77$ \\
& PH & $155.63 \pm 4.58^{* * * *}$ & $67.37 \pm 0.56^{* * * *}$ & $8.61 \pm 0.51^{* *}$ & $66.38 \pm 2.89 * *$ \\
\hline \multirow{2}{*}{ Leaf } & HM & $115.93 \pm 0.81$ & $37.40 \pm 0.45$ & $11.47 \pm 0.11$ & $84.24 \pm 0.83$ \\
& PH & $71.87 \pm 0.50^{* * * *}$ & $10.50 \pm 0.46^{* * * *}$ & $4.14 \pm 0.10^{* * * *}$ & $39.32 \pm 1.82^{* * * *}$ \\
\hline
\end{tabular}

The data are means \pm SEM from three replications. ${ }^{* *}$ indicates significant differences at $p<0.01,{ }^{* * * *}$ indicates significant differences at $p<0.0001$ (by $t$-test).

Antioxidants have been reported to have the ability to alleviate heavy metal toxicity. Thus, we determined whether the antioxidant status was altered in P. indica-colonized tobacco to cope with $\mathrm{Cd}^{2+}$ toxicity. Under Cd stress, the POD activity in P. indica-colonized tobacco reached $5.29 \mathrm{U}$ (mg protein $)^{-1}$, increasing by $18.08 \%$ compared with non-colonized tobacco (Figure 3C). Concomitantly, the GSH content of the PH group was $17.62 \mu \mathrm{mol} \cdot \mathrm{g}^{-1}$, $68.13 \%$ higher than that of the HM group. (Figure 3D). Overall, the findings indicated that $P$. indica elevated antioxidant levels as a detoxification strategy to neutralize $\mathrm{Cd}$ toxicity.

\subsection{Effect of P. indica on GSH Distribution in Root Cells}

GSH plays a central role in scavenging reactive oxygen species (ROS) to maintain redox homeostasis [37]. Sánchez-Illana had determined the GSH peaks by Raman spectra [38]. Among the wave numbers, a wavelength of 1647 was selected to visualize the GSH distribution. It showed that the colonization of P. indica changed the spatial distribution of the GSH in tobacco roots under Cd stress. GSH was concentrated in the cortical cells in P. indica-inoculation roots while in the epidermis of the non-inoculation roots (Figure 4).

\subsection{P. indica Can Absorb and Accumulate Cd}

Enhanced Cd tolerance conferred by $P$. indica has prompted us to investigate the underlying mechanism. Does $P$. indica protect tobacco from $\mathrm{Cd}$ toxicity by absorbing 
$\mathrm{Cd}$ into its body or neutralizing $\mathrm{Cd}$ or by inducing resistance in tobacco? Therefore, we first evaluated the cadmium tolerance of $P$. indica through culturing $P$. indica under a $\mathrm{Cd}$ gradient. When the $\mathrm{Cd}^{2+}$ concentration reached $2.5 \mathrm{mg} \cdot \mathrm{L}^{-1}$, fungal colony growth was inhibited entirely (Figure 5A). Thus, the minimum inhibitory concentration (MIC) value for $P$. indica was only $2.5 \mathrm{mg} \cdot \mathrm{L}^{-1}$, indicating that $P$. indica possessed the ability to absorb Cd, but its tolerance is not high (Figure $5 B$ ).

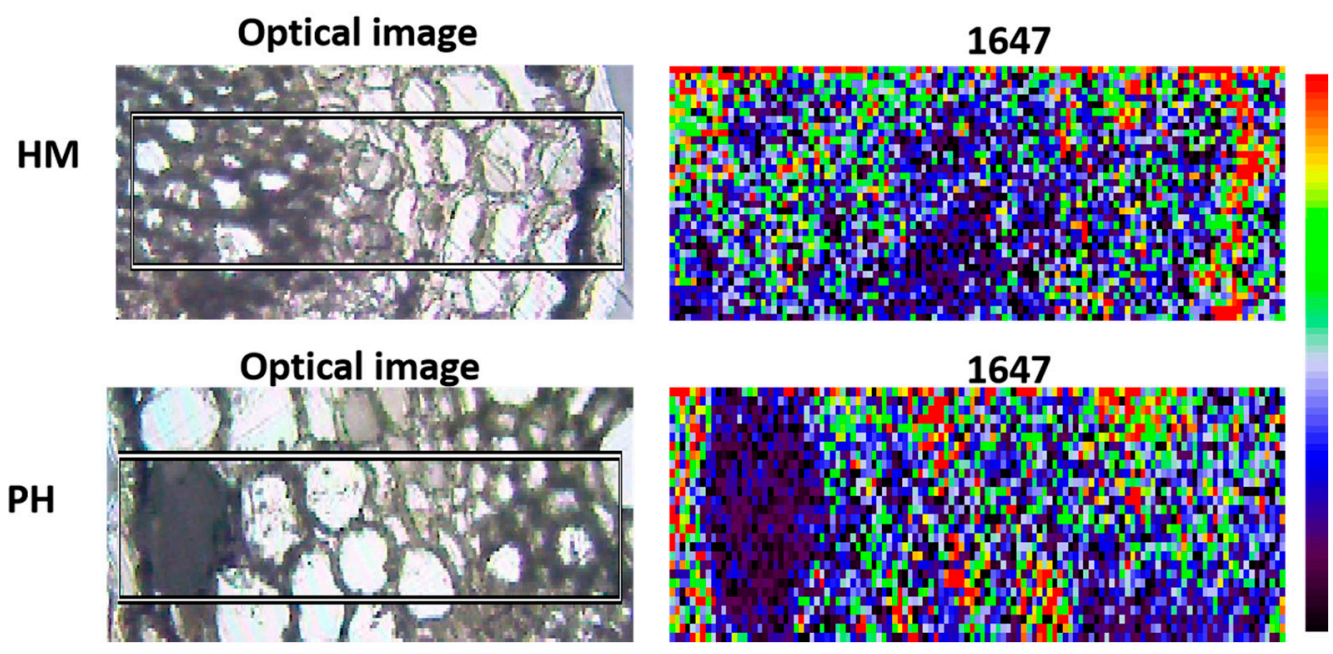

Figure 4. Raman microscopic images of GSH distribution in HM and PH root samples. Wave number $=1647$. Red indicates high concentration. Blue indicates low concentration.

Along the $\mathrm{Cd}$ gradient, the $\mathrm{Cd}$ content in mycelia increased from 0.217 to $1.765 \mathrm{mg} \cdot \mathrm{kg}^{-1}$ (Figure 5C). We further monitored the cellular distribution of $\mathrm{Cd}^{2+}$ by specific $\mathrm{Cd}^{2+}$ fluorescent dyes. It was found that the $\mathrm{Cd}^{2+}$ fluorescence signal was mainly concentrated in vacuoles of hyphae and chlamydospores (Figure 5D), suggesting that the vacuoles were the compartment to sequester $\mathrm{Cd}^{2+}$.

Under Cd stress, P. indica hyphae twisted (Figure 5E), and the number of chlamydospores significantly increased $(p<0.0001)$ (Figure 5E,F). The subcellular structures of $P$. indica under $\mathrm{Cd}$ stress were observed by TEM. The cell walls of chlamydospores were significantly thickened under the stress of $\mathrm{Cd}(p<0.01)$ (Figure $5 \mathrm{G}, \mathrm{H}$ ).

\subsection{Quantitative Proteomics of Tobacco and P. indica Interaction under Cd Stress}

Since the tolerance of $P$. indica to cadmium is low, it is speculated that $P$. indica could induce resistance of tobacco to $\mathrm{Cd}$ stress. Then, we conducted high-throughput label-free quantitative proteomics to compare the HM and PH tobacco plants. A total of 183 proteins were identified as differentially expressed proteins (DEPs) with a confidence of $>95 \%$ (Figure 6A, Table S1). Of these, 146 proteins were upregulated, and 37 proteins were downregulated (Figure 6B). Among these 183 proteins, 178 were plant proteins, and 5 were fungal proteins from $P$. indica (expressed inside the host plant roots). These five fungal proteins were actin-related protein (CCA73814.1), F-type $\mathrm{H}^{+}$-transporting ATPase subunit (CCA68781.1), FoF1-type ATP synthase alpha subunit (CCA74650.1), histone H3 (CCA72783.1), and F-box-WD40 repeat protein (CCA74347.1), respectively (Table S1). It is interesting to note that the five fungal proteins were uniformly upregulated (Table S1). Among the upregulated proteins, peroxidase proteins accounted for the highest proportion, with ten proteins. The second was photosystem II proteins. In addition, one thioredoxin 1 protein and one glutamine synthetase protein were also significantly upregulated (Table S1).

One hierarchical clustering showing differentially expressed proteins in $\mathrm{HM}$ and $\mathrm{PH}$ groups indicates that the root colonization by $P$. indica induced large changes in protein levels. Many significant DEPs were implicated in energy production and conversion, cellular processes, and signaling during Cd exposure (Table S1). 

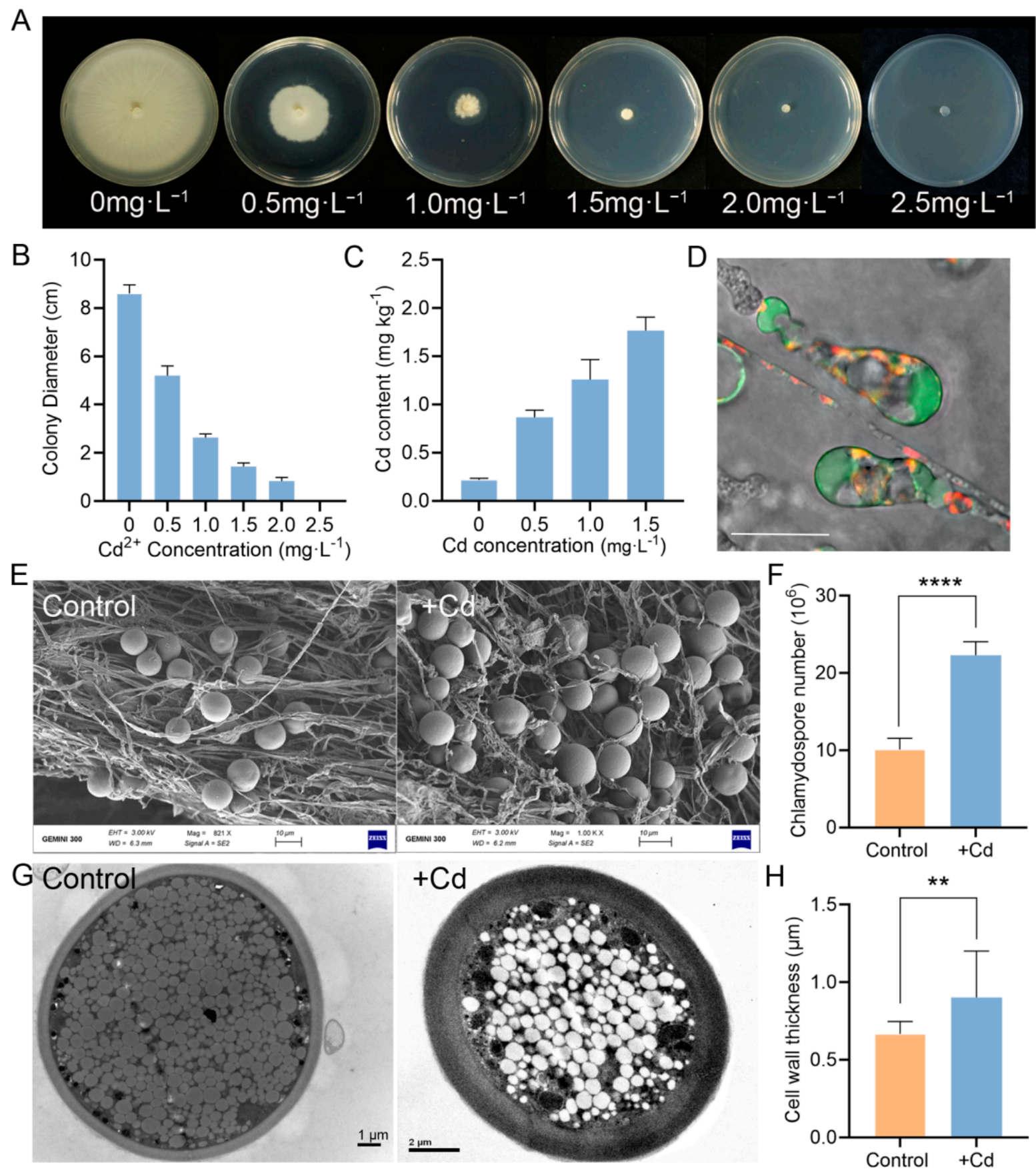

Figure 5. Cd tolerance assay of $P$. indica. (A) Colony morphology of $P$. indica exposed to different concentrations of Cd. (B) Fungal growth of $P$. indica cultured on different concentrations of $\mathrm{Cd}$ for 10 days. (C) The Cd accumulation in $P$. indica. (D) Cellular $\mathrm{Cd}^{2+}$ distribution in P. indica grown in PDA supplemented with $0.5 \mathrm{mg} \cdot \mathrm{L}^{-1} \mathrm{Cd}$ for 10 days. Scale bars $=10 \mu \mathrm{m}$. (E) Comparison of the fungal morphology of $P$. indica treated with 0 and $0.5 \mathrm{mg} \cdot \mathrm{L}^{-1}$ of Cd by SEM microscopy. (F) Effect of $\mathrm{Cd}$ on chlamydospore production. P. indica was treated with 0 and $0.5 \mathrm{mg} \cdot \mathrm{L}^{-1}$ of $\mathrm{Cd}$, respectively. (G) Scanning electron microscopy of chlamydospores. (H) Effect of Cd on chlamydospore cell wall thickness. P. indica was treated with 0 and $0.5 \mathrm{mg} \cdot \mathrm{L}^{-1}$ of $\mathrm{Cd}$, respectively. The bars represent the means \pm SDs. Significant differences $\left(t\right.$-test): ${ }^{* *}$ means $p<0.01$. $* * * *$ means $p<0.0001$.

\subsection{Functional Classification of Differentially Expressed Protein}

The Gene Ontology (GO) classification was performed for the identified differentially expressed proteins of the tobacco plant (Figure 7). A total of 136 out of 183 DEPs were annotated. The DEPs in the HM and PH groups covered a wide range of molecular functions 
(MF), biological processes (BP), and cellular components (CC). It was found that the major proportions of $50.74 \%(69 / 136)$ of proteins in the MF category were involved in the binding, which are essential components of biosynthesis, degradation, and energy-related reactions. In addition, $16.91 \%(23 / 136)$ of proteins engaged in ion binding, and $15.44 \%(21 / 136)$ of proteins engaged in metal iron-binding. In the BP category, $11.03 \%(15 / 136)$ of proteins engaged in photosynthesis, and $7.35 \%(10 / 136)$ of proteins were involved in response to oxidative stress. In the CC category, most proteins were concentrated in the photosystem II oxygen evolving complex (15/136), catalytic complex (13/136), extrinsic component of membrane (10/136), protein complex (17/136), membrane (15/136), chloroplast $(2 / 136)$. The rest of proteins are related to other biological regulation processes, such as antioxidant activity (11/136), peroxidase activity $(10 / 136)$, response to stress $(12 / 136)$, calcium ion binding (11/136), lipoate biosynthetic process (2/136), lipoate synthase activity $(2 / 136)$, and iron-sulfur cluster binding (1/136), etc.
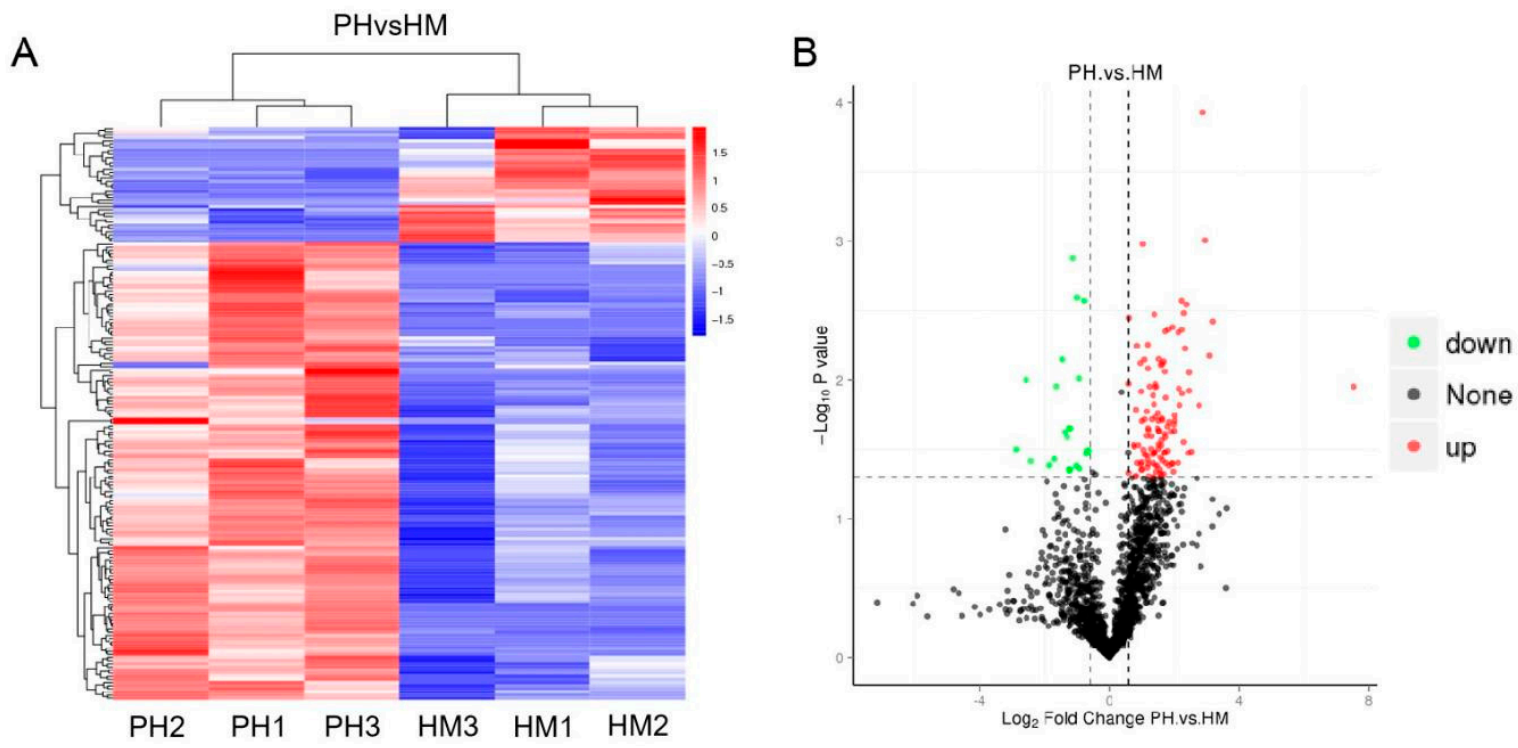

Figure 6. Differentially expressed proteins (DEPs) in Cd-treated tobacco plants inoculated with and without $P$. indica. (A) Heatmap of DEPs between HM and PH groups. Red, increase in expression abundance; blue, decrease in expression. Con1, Con2, and Con3 represent the control groups; Cd-1, Cd-2, and Cd-3 represent the Cd-treated groups. The horizontal axis represents the sample clusters. Similarity increases with decreasing cluster length. The clusters on the vertical axis indicate the expression modes of the clusters of proteins between $\mathrm{PH}$ and $\mathrm{HM}$ groups. The red and blue segments indicate relatively upregulated and downregulated protein expression, respectively. HM: Cd-treated plants; PH: both Cd-treated and P. indica-inoculated plants. (B) Volcano plot of the DEPs between the PH and HM groups. Red indicates significantly upregulated proteins. Green indicates significantly downregulated proteins. Black indicates proteins whose levels did not significantly differ between the two groups.

These biological pathways are also mapped in KEGG and were annotated in 20 KEGG pathways (Figure 8, Table S2). The KEGG pathway enrichment analysis determined the main metabolic and signal transduction pathways of the DEPs between the HM and $\mathrm{PH}$ groups. In addition, a bubble chart of the KEGG pathway was plotted. The KEGG pathway enrichment analysis indicated that the DEPs between the HM and PH groups were mainly related to phenylpropanoid biosynthesis (10 DEPs, $p<0.001)$, photosynthesis (10 DEPs, $p<0.01$ ), and metabolic pathways (57 DEPs, $p<0.05$ ).

Among the 183 DEPs between the HM and PH groups, 90 DEPs were annotated with a location. Most of the DEPs proteins were located in the chloroplast, accounting for $24.18 \%$, followed by the cytoplasm protein $(18.68 \%)$ and mitochondrion protein $(15.38 \%)$ (Figure 9). Cell membrane and cell wall proteins accounted for $8.79 \%$ and $7.69 \%$, respectively (Figure 9). It was suggested that the expression of the proteins on these organelles changed significantly in response to Cd stress. 


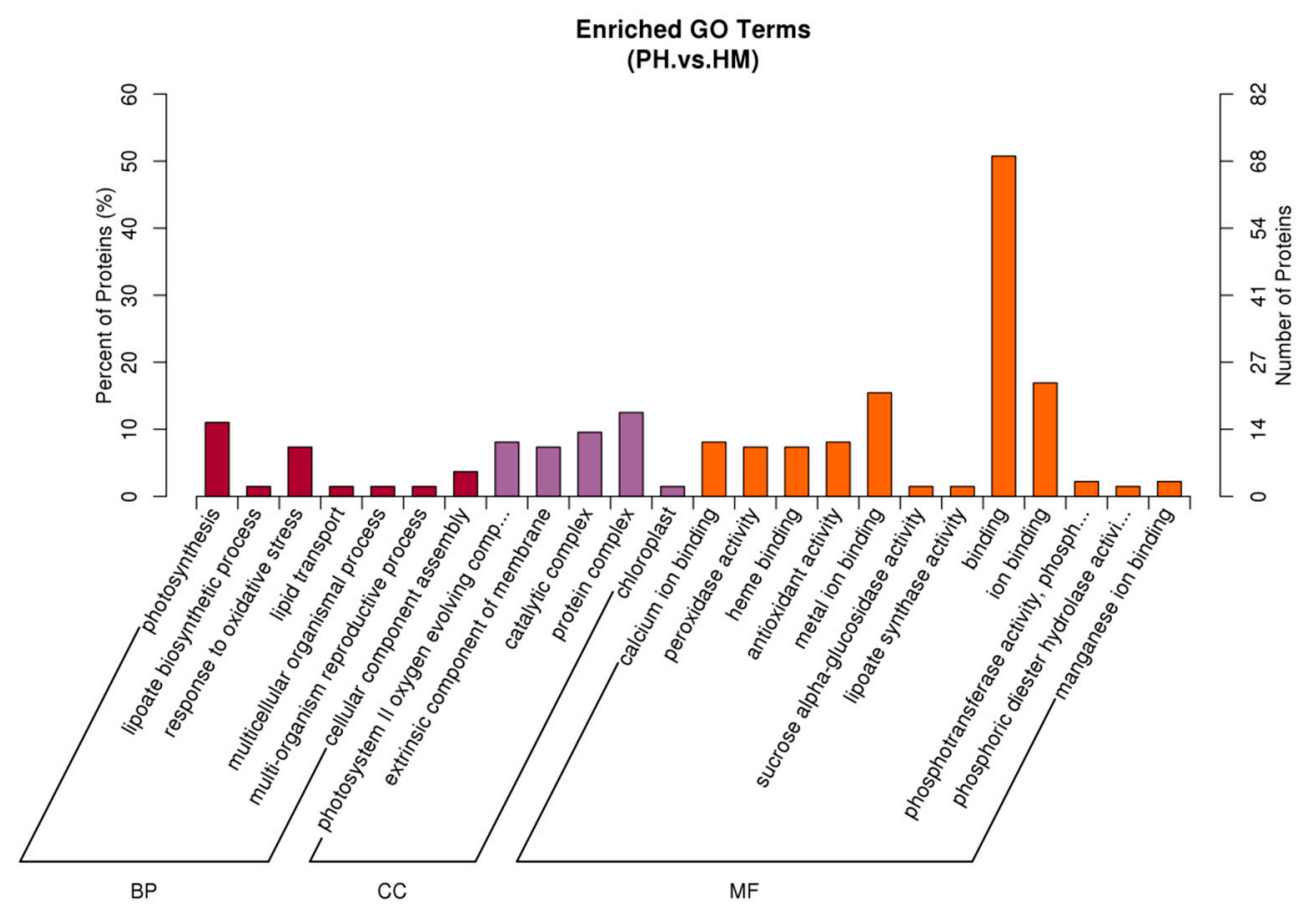

Figure 7. Gene Ontology analysis of the DEPs enriched in tobacco inoculated with/without $P$. indica during exposure to Cd (HM vs PH). GO is divided into three categories: (1) Biological Process (BP), which describes the biological processes of protein products; (2) Cellular Component (CC), which describes subcellular structure and location and macromolecular complexes; and (3) Molecular Function (MF), which describes the functions of proteins and their products.

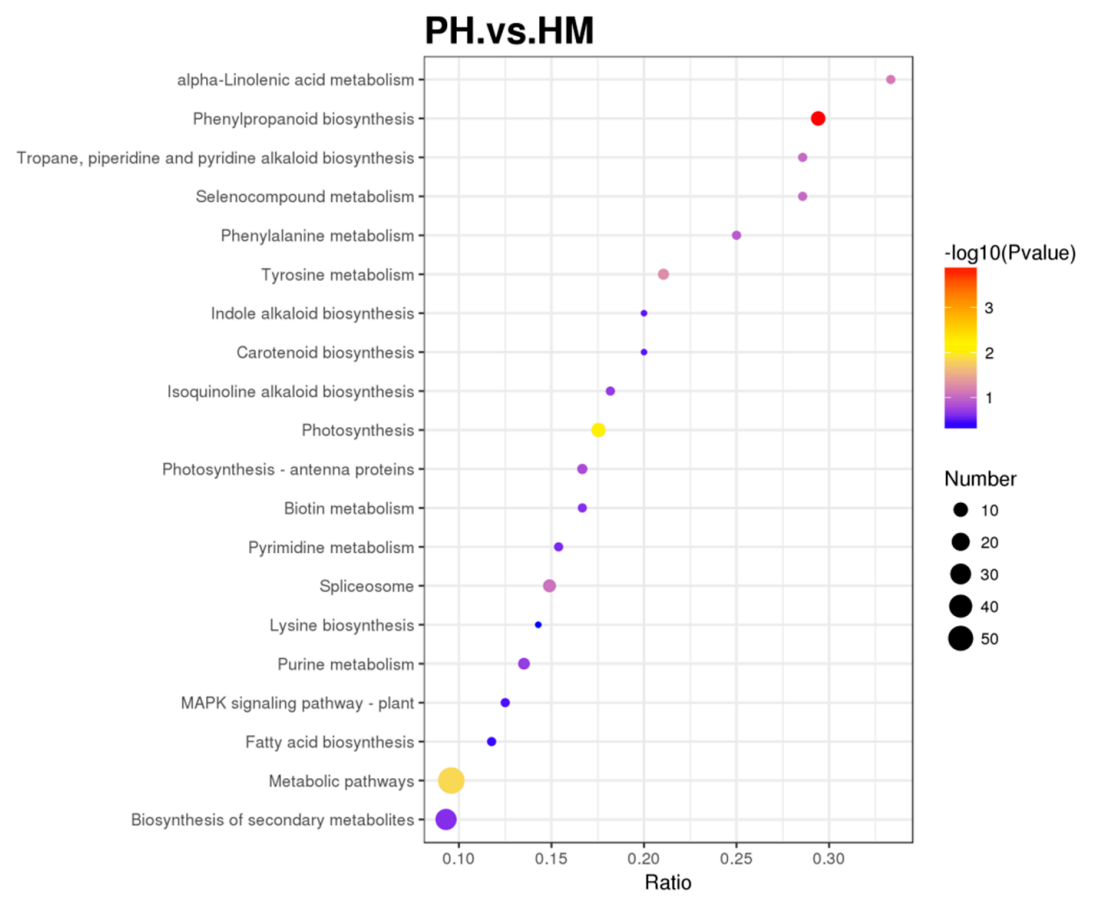

Figure 8. Kyoto Encyclopaedia of Genes and Genomes (KEGG) of the differentially expressed proteins (DEPs) between HM and PH groups. The horizontal axis represents the ratios of the number of DEPs in the corresponding pathways to the number of proteins detected. The DEPs enrichment level in each pathway increased with ratio magnitude. Dot color represents the $p$-value verified by a hypergeometric test. Test reliability and statistical significance increased with decreasing $p$-value. Dot size represents the number of DEPs in the corresponding pathway. The number of DEPs in the pathway increased with the total number of DEPs. 

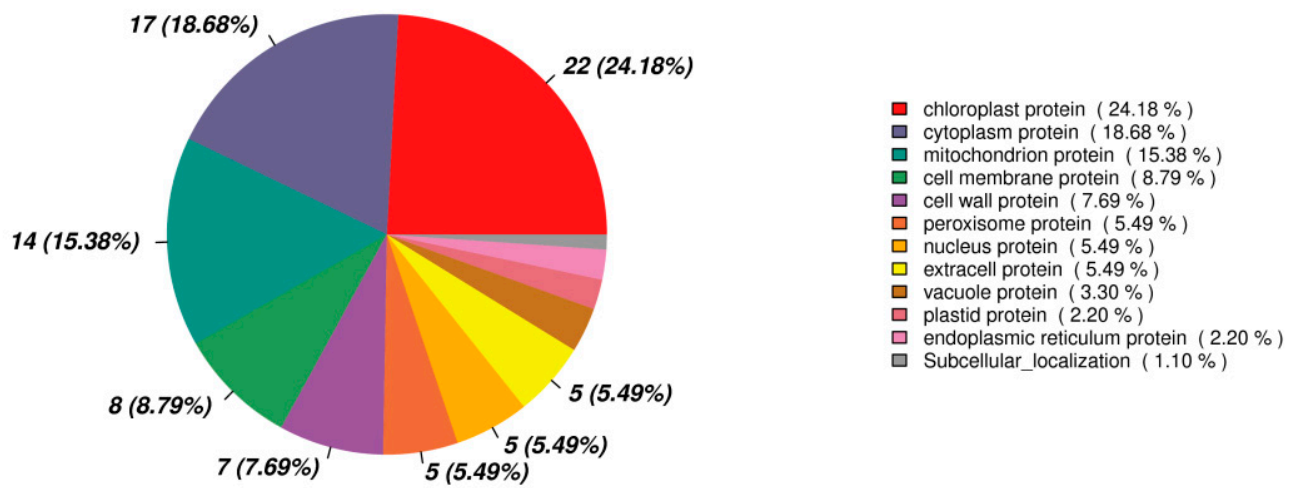

Figure 9. Subcellular localization of DEPs (HM vs PH).

\subsection{Protein-Protein Interaction (PPI) Analysis}

To explore the putative function and relationship of the $\mathrm{Cd}$ resistance responsive proteins induced by $P$. indica, we analyzed the functional overview of the DEPs using Cytoscape v2.8.3 software (confidence scores $\geq 0.5$ ). Figure 10 and Table S3 depicted the densely connected network, in which 98 DEPs were mapped to the tobacco proteininteractome database, and one protein was mapped to the $P$. indica protein-interactome database. The proteins centrally concentrated in translation, ribosomal structure and biogenesis, secondary metabolites biosynthesis, transport and catabolism, and energy production and conversion in this network. The findings were consistent with our GO enrichment and KEGG pathway analysis.

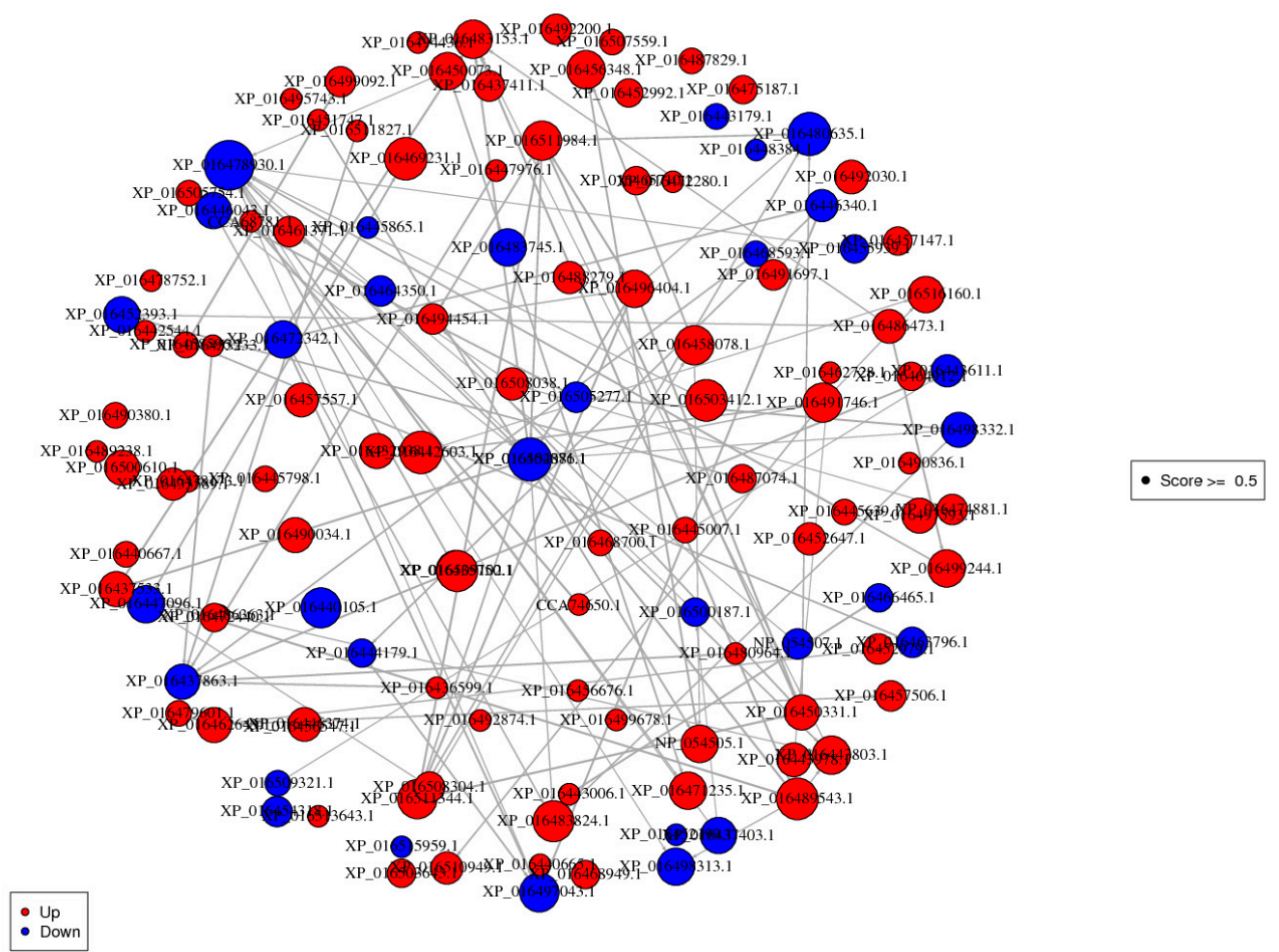

Figure 10. Protein-protein interaction networks of differentially expressed proteins. Red indicates significantly upregulated proteins. Blue indicates significantly downregulated proteins.

\section{Discussion}

Heavy metals usually have toxic effects on plants, such as low biomass accumulation, chlorosis, inhibition of growth and photosynthesis, changes in water balance and nutrient assimilation, senescence, etc., eventually leading to plant death [39]. In the present study, 
toxicity symptoms caused by $\mathrm{Cd}$ in tobacco were notable, such as chlorosis, dwarfing, reduced biomass, and root tissue damage. However, the root colonization of $P$. indica significantly alleviated the harmful effects of $\mathrm{Cd}$ and promoted the growth of tobacco. Furthermore, $P$. indica colonization increased the $\mathrm{Cd}$ accumulation in tobacco roots, thereby alleviating $\mathrm{Cd}$ toxicity, and decreased $\mathrm{Cd}$ accumulation in shoots. Therefore, it suggests that $P$. indica confers a marked $\mathrm{Cd}$ tolerance to its host plant and plays a functional role as a beneficial plant-associated fungus. Recently, $P$. indica has been extensively applied for alleviating heavy metal toxicity in kinds of plants, such as wheat [40], sunflower [30], Cassia angustifolia [41], and rice [42,43]. Shahabivand et al. [30] reported that $P$. indica inoculation also inhibited the transportation of $\mathrm{Cd}$ from roots to aerial tissues in sunflowers.

The detoxification capacity of plants partly depends on how they distribute toxins in their tissues [44]. The distribution pattern of metal ions in plant tissues is related to their toxicity and is vital for plant survival under toxic metal stress [45]. Cd can be accumulated in specific subcellular sites, such as vacuoles or cell walls, where Cd might be insolubly complexed to limit the translocation of $\mathrm{Cd}^{2+}$ strongly. Cell walls contain proteins and polysaccharides as ligands for binding metals and act as the first barrier against heavy metal entry into cells [46]. Therefore, plants bind heavy metals on the cell wall, which blocks the transmembrane transport of heavy metals to protoplasts to maintain the normal metabolism of plant cells [47]. Excessive accumulation of heavy metals in the plant membrane will damage cell activity and thus inhibit plant growth $[48,49]$. The current study showed that $P$. indica colonization modified a distinct subcellular alteration of $\mathrm{Cd}$ accumulation in both roots and leaves, significantly increasing the proportion of cell-wall-bound Cd. Simultaneously, a significant reduction in Cd accumulation in the other subcellular fractions, especially membrane/organelle and soluble-Cd, alleviated the adverse effects of excessive $\mathrm{Cd}$ accumulation in both leaves and roots of $P$. indica-inoculated tobacco. It is suggested that $P$. indica enhanced the capacity of binding metal ions in the cell walls of roots and shoots. Arbuscular mycorrhizal fungus Glomus intraradices protected alfalfa (Medicago sativa L.) from Cd toxicity by increasing the proportion of Cd in cell walls, and reducing the proportion in organelles/membranes [44]. Dark septate endophyte Exophiala pisciphila distributed $\mathrm{Cd}$ into the cell walls and changed $\mathrm{Cd}^{2+}$ into inactive forms; thus, the host plant grew normally even under Cd stress [45]. Taken together, $P$. indica improved the $\mathrm{Cd}$ tolerance of tobacco by regulating the repartition of $\mathrm{Cd}$ in subcellular components. P. indica-colonized tobacco plants employ cell walls as the primary reservoir for Cd.

Fungi-assisted phytoremediation of heavy metals is by two ways: directly (through fungal absorption) or indirectly (through improving tolerance in the host plant) [19]. Fungi possess unique tolerance mechanisms to overcome heavy metal stress, such as chelation of extracellular heavy metals, binding of heavy metals on cell walls, complexation, and segregation of intracellular heavy metals [50]. In the present study, P. indica formed abundant chlamydospores with thickened cell walls to withstand the $\mathrm{Cd}$ toxicity. P. indica accumulated $\mathrm{Cd}^{2+}$ in chlamydospores and employed vacuole sequestration as a survival strategy under $\mathrm{Cd}$ stress. Accumulation of heavy metals by spores has been found in many AM fungi, which is a way for sequestering heavy metals and protecting plants from heavy metal stress [51,52]. Additionally, Mohd et al. [42] also reported that $P$. indica accumulated arsenic in vacuoles and cell walls of spores. Overall, our findings indicated that $P$. indica served as a biofilter sequestering $\mathrm{Cd}^{2+}$ in its vacuoles, prevented $\mathrm{Cd}^{2+}$ from being absorbed by the tobacco, immobilized $\mathrm{Cd}$ in the roots, and reduced the $\mathrm{Cd}$ accumulation in leaves.

Besides its accumulation capacity of $\mathrm{Cd}, P$. indica also induced tobacco resistance to alleviate $\mathrm{Cd}$ toxicity. A symbiont of $P$. indica-tobacco possesses a sophisticated and interrelated detoxification network for $\mathrm{Cd}$ detoxification (Figure 11). According to the proteomics, the DEPs were mainly enriched in the oxidation-reduction process, carbohydrate and lipid metabolism, energy synthesis, and protein regulation during $\mathrm{Cd}$ exposure. These metabolic pathways were interconnected and endowed tobacco with tolerance to $\mathrm{Cd}$ through several aspects: (1) P. indica enhanced the resistance of tobacco to $\mathrm{Cd}$ by increasing the expression 
of POD. All plants produce various antioxidants and enzymatic scavengers to reduce the oxidative damage caused by $\mathrm{Cd}[53,54]$. POD is a defense enzyme that works with superoxide dismutase and catalase to remove excess ROS caused by heavy metals. P. indica employed peroxidase to detoxify the $\mathrm{Cd}$ toxicity in tobacco. (2) P. indica enhanced the photosynthetic efficiency of tobacco and ensured energy supply even under $\mathrm{Cd}$ stress. It has been reported that $P$. indica improved photosynthetic pigments under arsenic [42], Cd [30], and copper [41]. Jogawat et al. [55] found that the colonization of $P$. indica increased the chlorophyll contents by upregulating the expression of the chlorophyll synthesis-related genes in rice seedlings under arsenic toxicity. Ghorbani et al. [56] reported that $P$. indica increased photosynthetic pigments to improve photosynthetic efficiency. Shahabivand et al. [30] also documented that $P$. indica promoted photosynthesis by improving electron transfer and the utilization of light energy under $\mathrm{Cd}$ toxicity. $\mathrm{Cd}$ stress also inhibited photosynthetic activities $[57,58]$. In the current work, tobacco plants turned to chlorosis under Cd stress. However, the P. indica-colonization in tobacco roots eliminated this chlorosis. Significant upregulation of the proteins involved in photosystem II (including photosystem II oxygen-evolving enhancer protein, photosystem II 13kDa protein, and photosystem II Psb27 protein) indicated that $P$. indica enhanced the photosynthesis in tobacco. Photosynthesis in P. indica-colonized tobacco leaves remained working normally even under Cd stress. (3) The enhancement of GSH regulated by glutathione synthase (GS) participated in Cd chelation in P. indica-colonized tobacco roots. Metal chelation is an essential detoxification mechanism for plants to combat heavy metal toxicity [59]. Chelation can be carried out by thiol compounds, such as glutathione [37], phytochelatins (PCs) [60], and metallothioneins (MTs) [61]. In particular, GSH participates in scavenging the accumulation of free radicals and reducing oxidative stress caused by heavy metals. Glutathione synthase (GS) catalyzed the biosynthesis of GSH. In Arabidopsis thaliana and Schizosaccharomyces pombe, the expression of GS was significantly increased in response to Cd [62,63]. Estrella-Gómez et al. [64] also showed that Salvinia minima plants increased resistance to $\mathrm{Pb}$ exposure by increasing GSH concentration, GS activity, and the SmGS expression level. Thus, GS is positively correlated with the heavy metal resistance of plants. This work found that the GS protein exhibited a higher accumulation in P. indica-inoculated tobacco roots, and the GSH content was enhanced and distributed in cortical cells. Thus, $P$. indica could help tobacco resist $\mathrm{Cd}$ toxicity by regulating the content and distribution of GSH. In addition, GS is also an essential enzyme for the assimilation and absorption of inorganic nitrogen. GS has been reported to enhance the biomass of some crops [65], including maize [66], wheat [67,68], and rice [69]. Therefore, the colonization of $P$. indica also enhanced the assimilation of inorganic nitrogen of tobacco roots, by which the host growth was promoted. (4) P. indica-colonized tobacco also employed a thioredoxin system to detoxify $\mathrm{Cd}$ toxicity. There are two thiol systems to maintain the cellular redox state in organisms. One is a low-molecular-weight thiol system, typically GSH [70]; the other is the thioredoxin system [71]. Thioredoxins can directly reduce or sequester heavy metals, and the resulting thioredoxin-heavy metal complex can be resolved by thioredoxin reductase leading to heavy metal detoxification [72]. Therefore, the enhanced Cd tolerance of tobacco induced by P. indica was correlated to the upregulation of thioredoxin protein. 


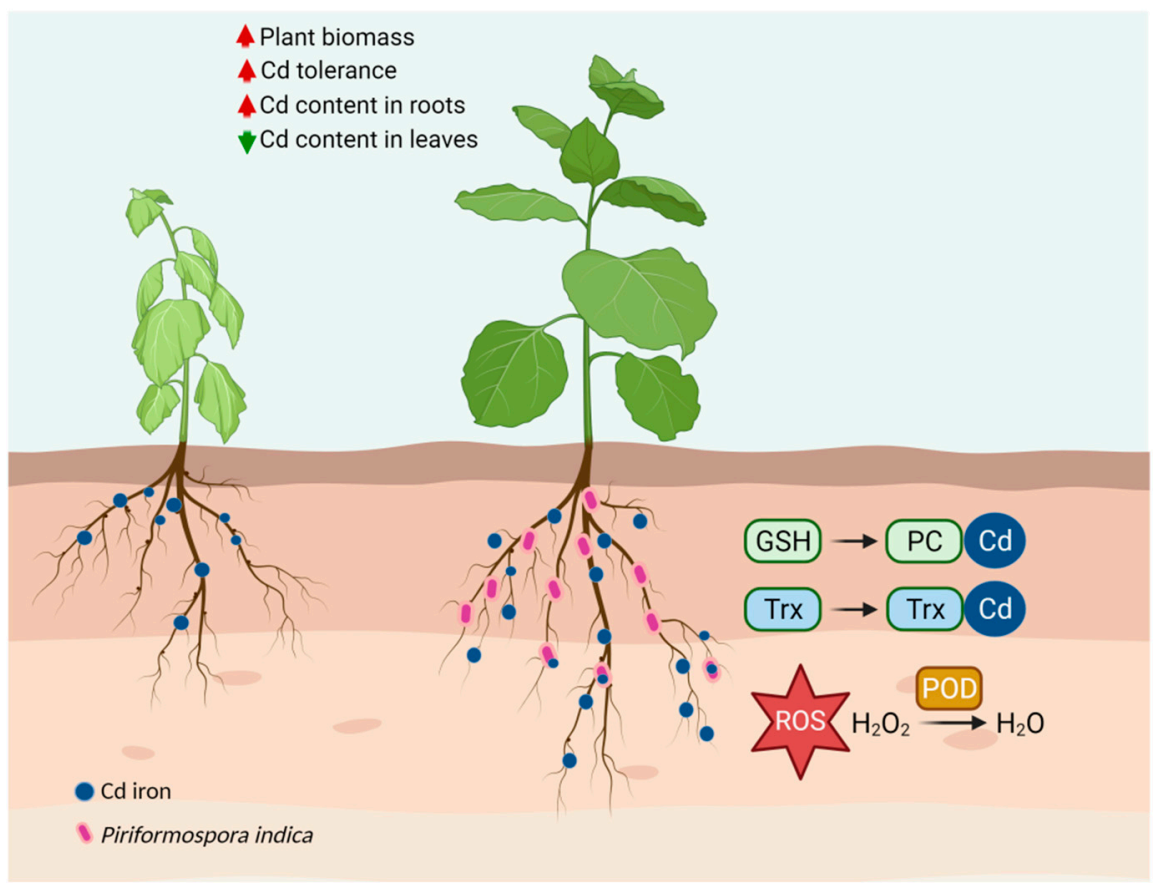

Figure 11. Schematic illustration of the mechanism for Cd detoxification in tobacco induced by P. indica. P. indica-inoculated tobacco possesses a sophisticated Cd detoxification network, including GSH, POD, and thioredoxin (Trx). Metal ions are shown as dark blue granular. P. indica is shown as pink granular.

\section{Conclusions}

In summary, $P$. indica partnered with tobacco roots improved host $\mathrm{Cd}$ tolerance, increased Cd content in tobacco roots by $108.73 \%$, and reduced $\mathrm{Cd}$ content in leaves by $47.42 \%$. P. indica accumulated $\mathrm{Cd}^{2+}$ into its chlamydospores and vacuoles, thereby preventing $\mathrm{Cd}^{2+}$ from being absorbed by the tobacco. P. indica increased the proportion of $\mathrm{Cd}$ in cell walls while reducing the proportion in organelles/membranes and soluble $\mathrm{Cd}$. P. indica significantly enhanced the POD activity and GSH content in tobacco. Moreover, GSH was distributed in the cortex of $P$. indica-inoculated roots while in the epidermis of the control roots under $\mathrm{Cd}$ stress. The proteomics data showed that the proteins involved in peroxidase, GSH, and the thioredoxin system were enhanced by P. indica to detoxify the $\mathrm{Cd}$ toxicity in tobacco. Our findings indicate great potential for the application of this symbiosis in sustainable agriculture and phytoremediation.

Supplementary Materials: The following are available online at https: / www.mdpi.com/article / 10.3390/jof7080675/s1, Table S1: Differentially expressed proteins in PH vs. HM; Table S2: KEGG pathways; Table S3: Protein-protein interaction network.

Author Contributions: Conceptualization, Z.S., X.L. (Xiaoli Li), and F.L.; Data curation, Z.S.; Formal analysis, Z.S., Y.Z., J.Z., X.L. (Xuanjun Lu), M.D., and X.L. (Xiaohong Liu); Funding acquisition, Z.S. and F.L.; Investigation, Z.S.; Methodology, Z.S., X.L. (Xiaoli Li), and A.B.P.; Project administration, Z.S. and F.L.; Resources, Z.S.; Software, Z.S., X.L. (Xiaoli Li), and A.B.P.; Supervision, F.L.; Validation, Z.S., X.L. (Xiaoli Li), and F.L.; Visualization, X.L. (Xiaoli Li) and A.B.P.; Writing—original draft, Z.S.; Writing-review and editing, Z.S., X.L. (Xiaoli Li), and F.L. All authors have read and agreed to the published version of the manuscript.

Funding: This research was funded by the Public Technology Research Program of Zhejiang Province, grant number LGN20C030002, the Provincial Key Research and Development Plan of Zhejiang, grant number 2019C02010, and The APC was funded by LGN20C030002.

Institutional Review Board Statement: Not applicable.

Informed Consent Statement: Not applicable. 
Data Availability Statement: The data presented in this study are available on request from the corresponding author.

Acknowledgments: We would like to thank Zhen-Yu Qi from the agricultural experiment station of Zhejiang University for his assistance during the experiment.

Conflicts of Interest: The authors declare no conflict of interest. The funders had no role in the design of the study; in the collection, analyses, or interpretation of data; in the writing of the manuscript; or in the decision to publish the results.

\section{References}

1. Qin, G.; Niu, Z.; Yu, J.; Li, Z.; Ma, J.-Y.; Xiang, P. Soil heavy metal pollution and food safety in China: Effects, sources and removing technology. Chemosphere 2020, 267, 129205. [CrossRef] [PubMed]

2. Alekseenko, V.A.; Bech, J.; Alekseenko, A.; Shvydkaya, N.V.; Roca, N. Environmental impact of disposal of coal mining wastes on soils and plants in Rostov Oblast, Russia. J. Geochem. Explor. 2018, 184, 261-270. [CrossRef]

3. Chen, H.; Yang, X.; Wang, P.; Wang, Z.; Li, M.; Zhao, F.-J. Dietary cadmium intake from rice and vegetables and potential health risk: A case study in Xiangtan, southern China. Sci. Total Environ. 2018, 639, 271-277. [CrossRef]

4. Hall, J.L. Cellular mechanisms for heavy metal detoxification and tolerance. J. Exp. Bot. 2002, 53, 1-11. [CrossRef] [PubMed]

5. Xu, J.; Yin, H.; Li, X. Protective effects of proline against cadmium toxicity in micropropagated hyperaccumulator, Solanum nigrum L. Plant Cell Rep. 2008, 28, 325-333. [CrossRef] [PubMed]

6. Dias, M.C.; Monteiro, M.; Moutinho-Pereira, J.; Correia, C.; Gonçalves, B.; Santos, C. Cadmium toxicity affects photosynthesis and plant growth at different levels. Acta Physiol. Plant. 2012, 35, 1281-1289. [CrossRef]

7. Ge, J.; Wang, H.; Lin, J.; Tian, S.; Zhao, J.; Lin, X.; Lu, L. Nickel tolerance, translocation and accumulation in a Cd/Zn cohyperaccumulator plant Sedum alfredii. J. Hazard. Mater. 2020, 398, 123074. [CrossRef] [PubMed]

8. Xv, L.; Ge, J.; Tian, S.; Wang, H.; Yu, H.; Zhao, J.; Lu, L. A Cd/Zn Co-hyperaccumulator and Pb accumulator, Sedum alfredii, is of high Cu tolerance. Environ. Pollut. 2020, 263, 114401. [CrossRef] [PubMed]

9. Vamerali, T.; Bandiera, M.; Mosca, G. Field crops for phytoremediation of metal-contaminated land. A review. Environ. Chem. Lett. 2009, 8, 1-17. [CrossRef]

10. Wagner, G.J.; Yeargan, R. Variation in Cadmium Accumulation Potential and Tissue Distribution of Cadmium in Tobacco. Plant Physiol. 1986, 82, 274-279. [CrossRef]

11. Liu, H.; Wang, H.; Ma, Y.; Wang, H.; Shi, Y. Role of transpiration and metabolism in translocation and accumulation of cadmium in tobacco plants (Nicotiana tabacum L.). Chemosphere 2016, 144, 1960-1965. [CrossRef] [PubMed]

12. Liu, H.; Zhang, Y.; Zhou, X.; You, X.; Shi, Y.; Xu, J. Source identification and spatial distribution of heavy metals in tobacco-growing soils in Shandong province of China with multivariate and geostatistical analysis. Environ. Sci. Pollut. Res. 2017, 24, 5964-5975. [CrossRef]

13. Liu, H.; Wang, H.; Zhang, Y.; Yuan, J.; Peng, Y.; Li, X.; Shi, Y.; He, K.; Zhang, Q. Risk assessment, spatial distribution, and source apportionment of heavy metals in Chinese surface soils from a typically tobacco cultivated area. Environ. Sci. Pollut. Res. 2018, 25, 16852-16863. [CrossRef] [PubMed]

14. Jiang, Y.; Han, J.; Xue, W.; Wang, J.; Wang, B.; Liu, L.; Zou, J. Overexpression of SmZIP plays important roles in Cd accumulation and translocation, subcellular distribution, and chemical forms in transgenic tobacco under Cd stress. Ecotoxicol. Environ. Saf. 2021, 214, 112097. [CrossRef] [PubMed]

15. Lugon-Moulin, N.; Martin, F.; Krauss, M.R.; Ramey, P.B.; Rossi, L. Cadmium concentration in tobacco (Nicotiana tabacum L.) from different countries and its relationship with other elements. Chemosphere 2006, 63, 1074-1086. [CrossRef] [PubMed]

16. Tiodar, E.; Văcar, C.; Podar, D. Phytoremediation and Microorganisms-Assisted Phytoremediation of Mercury-Contaminated Soils: Challenges and Perspectives. Int. J. Environ. Res. Public Health 2021, 18, 2435. [CrossRef]

17. Likar, M.; Regvar, M. Isolates of dark septate endophytes reduce metal uptake and improve physiology of Salix caprea L. Plant Soil 2013, 370, 593-604. [CrossRef]

18. Wang, G.; Wang, L.; Ma, F. Effects of earthworms and arbuscular mycorrhizal fungi on improvement of fertility and micro-bial communities of soils heavily polluted by cadmium. Chemosphere 2021, 286 Pt 2, 131567. [CrossRef]

19. Riaz, M.; Kamran, M.; Fang, Y.; Wang, Q.; Cao, H.; Yang, G.; Deng, L.; Wang, Y.; Zhou, Y.; Anastopoulos, I.; et al. Arbuscular mycorrhizal fungi-induced mitigation of heavy metal phytotoxicity in metal contaminated soils: A critical review. J. Hazard. Mater. 2020, 402, 123919. [CrossRef]

20. Newsham, K.K. A meta-analysis of plant responses to dark septate root endophytes. New Phytol. 2011, 190, 783-793. [CrossRef]

21. Su, Z.-Z.; Dai, M.-D.; Zhu, J.-N.; Liu, X.-H.; Li, L.; Zhu, X.-M.; Wang, J.-Y.; Yuan, Z.-L.; Lin, F.-C. Dark septate endophyte Falciphora oryzae-assisted alleviation of cadmium in rice. J. Hazard. Mater. 2021, 419, 126435. [CrossRef]

22. Dubey, A.; Malla, M.A.; Kumar, A.; Dayanandan, S.; Khan, M.L. Plants endophytes: Unveiling hidden agenda for bioprospecting toward sustainable agriculture. Crit. Rev. Biotechnol. 2020, 40, 1210-1231. [CrossRef]

23. He, W.; Megharaj, M.; Wu, C.-Y.; Subashchandrabose, S.R.; Dai, C.-C. Endophyte-assisted phytoremediation: Mechanisms and current application strategies for soil mixed pollutants. Crit. Rev. Biotechnol. 2019, 40, 31-45. [CrossRef] 
24. Wani, Z.A.; Ashraf, N.; Mohiuddin, T.; Riyaz-Ul-Hassan, S. Plant-endophyte symbiosis, an ecological perspective. Appl. Microbiol. Biotechnol. 2015, 99, 2955-2965. [CrossRef]

25. Verma, S.; Varma, A.; Rexer, K.-H.; Hassel, A.; Kost, G.; Sarbhoy, A.; Bisen, P.; Bütehorn, B.; Franken, P. Piriformospora indica, gen. et sp. nov., a new root-colonizing fungus. Mycologia 1998, 90, 896-903. [CrossRef]

26. Fakhro, A.; Andrade-Linares, D.R.; Von Bargen, S.; Bandte, M.; Büttner, C.; Grosch, R.; Schwarz, D.; Franken, P. Impact of Piriformospora indica on tomato growth and on interaction with fungal and viral pathogens. Mycorrhiza 2009, 20, 191-200. [CrossRef] [PubMed]

27. Peskan-Berghofer, T.; Shahollari, B.; Giong, P.H.; Hehl, S.; Markert, C.; Blanke, V.; Kost, G.; Varma, A.; Oelmuller, R. Association of Piriformospora indica with Arabidopsis thaliana roots represents a novel system to study beneficial plant-microbe interactions and involves early plant protein modifications in the endoplasmic reticulum and the plasma membrane. Physiol. Plant. 2004, 122, 465-477. [CrossRef]

28. Becker, N.A.; Maher, L.J.; Iii, N.A.B.J.M. LMPCR for Detection of Oligonucleotide-Directed Triple Helix Formation: A Cautionary Note. Antisense Nucleic Acid Drug Dev. 1999, 9, 313-316. [CrossRef] [PubMed]

29. Waller, F.; Achatz, B.; Baltruschat, H.; Fodor, J.; Becker, K.; Fischer, M.; Heier, T.; Hückelhoven, R.; Neumann, C.; von Wettstein, D.; et al. The endophytic fungus Piriformospora indica reprograms barley to salt-stress tolerance, disease resistance, and higher yield. Proc. Natl. Acad. Sci. USA 2005, 102, 13386-13391. [CrossRef] [PubMed]

30. Shahabivand, S.; Parvaneh, A.; Aliloo, A.A. Root endophytic fungus Piriformospora indica affected growth, cadmium partitioning and chlorophyll fluorescence of sunflower under cadmium toxicity. Ecotoxicol. Environ. Saf. 2017, 145, 496-502. [CrossRef] [PubMed]

31. Ghorbani, A.; Tafteh, M.; Roudbari, N.; Pishkar, L.; Zhang, W.; Wu, C. Piriformospora indica augments arsenic tolerance in rice (Oryza sativa) by immobilizing arsenic in roots and improving iron translocation to shoots. Ecotoxicol. Environ. Saf. 2020, 209, 111793. [CrossRef] [PubMed]

32. Wu, F.-B.; Dong, J.; Qian, Q.Q.; Zhang, G.-P. Subcellular distribution and chemical form of Cd and Cd-Zn interaction in different barley genotypes. Chemosphere 2005, 60, 1437-1446. [CrossRef]

33. Klionsky, D.J.; Herman, P.K.; Emr, S.D. The fungal vacuole: Composition, function, and biogenesis. Microbiol. Rev. 1990, 54, 266-292. [CrossRef] [PubMed]

34. Patra, K.C.; Hay, N. The pentose phosphate pathway and cancer. Trends Biochem. Sci. 2014, 39, 347-354. [CrossRef]

35. Wickner, W. Membrane Fusion: Five Lipids, Four SNAREs, Three Chaperones, Two Nucleotides, and a Rab, All Dancing in a Ring on Yeast Vacuoles. Annu. Rev. Cell Dev. Biol. 2010, 26, 115-136. [CrossRef]

36. Sharma, S.S.; Yamamoto, K.; Hamaji, K.; Ohnishi, M.; Anegawa, A.; Sharma, S.; Thakur, S.; Kumar, V.; Uemura, T.; Nakano, A.; et al. Cadmium-induced changes in vacuolar aspects of Arabidopsis thaliana. Plant Physiol. Biochem. 2017, 114, 29-37. [CrossRef]

37. Seth, C.S.; Remans, T.; Keunen, E.; Jozefczak, M.; Gielen, H.; Opdenakker, K.; Weyens, N.; Vangronsveld, J.; Cuypers, A. Phytoextraction of toxic metals: A central role for glutathione. Plant Cell Environ. 2011, 35, 334-346. [CrossRef]

38. Sánchez-Illana, A.; Mayr, F.; Cuesta-García, D.; Piñeiro-Ramos, J.D.; Cantarero, A.; De La Guardia, M.; Vento, M.; Lendl, B.; Quintás, G.; Kuligowski, J. On-Capillary Surface-Enhanced Raman Spectroscopy: Determination of Glutathione in Whole Blood Microsamples. Anal. Chem. 2018, 90, 9093-9100. [CrossRef]

39. Singh, S.; Parihar, P.; Singh, R.; Singh, V.P.; Prasad, S.M. Heavy Metal Tolerance in Plants: Role of Transcriptomics, Proteomics, Metabolomics, and Ionomics. Front. Plant Sci. 2016, 6, 1143. [CrossRef] [PubMed]

40. Shahabivand, S.; Maivan, H.Z.; Goltapeh, E.M.; Sharifi, M.; Aliloo, A.A. The effects of root endophyte and arbuscular mycorrhizal fungi on growth and cadmium accumulation in wheat under cadmium toxicity. Plant Physiol. Biochem. 2012, 60, 53-58. [CrossRef] [PubMed]

41. Nanda, R.; Agrawal, V. Piriformospora indica, an excellent system for heavy metal sequestration and amelioration of oxidative stress and DNA damage in Cassia angustifolia Vahl under copper stress. Ecotoxicol. Environ. Saf. 2018, 156, 409-419. [CrossRef]

42. Mohd, S.; Shukla, J.; Kushwaha, A.S.; Mandrah, K.; Shankar, J.; Arjaria, N.; Saxena, P.N.; Narayan, R.; Roy, S.K.; Kumar, M. Endophytic Fungi Piriformospora indica Mediated Protection of Host from Arsenic Toxicity. Front. Microbiol. 2017, 8, 754. [CrossRef]

43. Dabral, S.; Yashaswee; Varma, A.; Choudhary, D.K.; Bahuguna, R.N.; Nath, M. Biopriming with Piriformospora indica ameliorates cadmium stress in rice by lowering oxidative stress and cell death in root cells. Ecotoxicol. Environ. Saf. 2019, $186,109741$. [CrossRef] [PubMed]

44. Wang, Y.; Huang, J.; Gao, Y. Arbuscular Mycorrhizal Colonization Alters Subcellular Distribution and Chemical Forms of Cadmium in Medicago sativa L. and Resists Cadmium Toxicity. PLoS ONE 2012, 7, e48669. [CrossRef] [PubMed]

45. Wang, J.-L.; Jun-Ling, W.; Liu, G.-Y.; Smith, J.M.; Zhao, Z.-W. Unraveling the role of dark septate endophyte (DSE) colonizing maize (Zea mays) under cadmium stress: Physiological, cytological and genic aspects. Sci. Rep. 2016, 6, 22028. [CrossRef] [PubMed]

46. Yang, J.L.; Zhu, X.F.; Peng, Y.X.; Zheng, C.; Li, G.X.; Liu, Y.; Shi, Y.Z.; Zheng, S.J. Cell Wall Hemicellulose Contributes Significantly to Aluminum Adsorption and Root Growth in Arabidopsis. Plant Physiol. 2011, 155, 1885-1892. [CrossRef]

47. Jia, H.; Wang, X.; Wei, T.; Wang, M.; Liu, X.; Hua, L.; Ren, X.; Guo, J.; Li, J. Exogenous salicylic acid regulates cell wall polysaccharides synthesis and pectin methylation to reduce Cd accumulation of tomato. Ecotoxicol. Environ. Saf. 2020, $207,111550$. [CrossRef] [PubMed] 
48. Liu, D.; Kottke, I. Subcellular localization of copper in the root cells of Allium sativum by electron energy loss spectroscopy (EELS). Bioresour. Technol. 2004, 94, 153-158. [CrossRef]

49. Muñoz, A.H.S.; Kubachka, K.; Wrobel, K.; Corona, J.F.G.; Yathavakilla, S.K.V.; Caruso, J.A.; Wrobel, K. Se-Enriched Mycelia ofPleurotus ostreatus: Distribution of Selenium in Cell Walls and Cell Membranes/Cytosol. J. Agric. Food Chem. 2006, 54, 3440-3444. [CrossRef]

50. Xu, X.; Xia, L.; Huang, Q.; Gu, J.-D.; Chen, W. Biosorption of cadmium by a metal-resistant filamentous fungus isolated from chicken manure compost. Environ. Technol. 2012, 33, 1661-1670. [CrossRef]

51. González-Guerrero, M.; Melville, L.H.; Ferrol, N.; Lott, J.N.; Azcon, C.; Peterson, R.L. Ultrastructural localization of heavy metals in the extraradical mycelium and spores of the arbuscular mycorrhizal fungus Glomus intraradices. Can. J. Microbiol. 2008, 54, 103-110. [CrossRef] [PubMed]

52. Aguilera, P.; Borie, F.; Seguel, A.; Cornejo, P. Fluorescence detection of aluminum in arbuscular mycorrhizal fungal structures and glomalin using confocal laser scanning microscopy. Soil Biol. Biochem. 2011, 43, 2427-2431. [CrossRef]

53. Su, Z.-Z.; Mao, L.-J.; Li, N.; Feng, X.-X.; Yuan, Z.-L.; Wang, L.-W.; Lin, F.-C.; Zhang, C.-L. Evidence for Biotrophic Lifestyle and Biocontrol Potential of Dark Septate Endophyte Harpophora oryzae to Rice Blast Disease. PLoS ONE 2013, 8, e61332. [CrossRef]

54. Zhu, T.; Li, L.; Duan, Q.; Liu, X.; Chen, M. Progress in our understanding of plant responses to the stress of heavy metal cadmium. Plant Signal. Behav. 2020, 16, 1836884. [CrossRef] [PubMed]

55. Jogawat, A.; Saha, S.; Bakshi, M.; Dayaman, V.; Kumar, M.; Dua, M.; Varma, A.; Oelmüller, R.; Tuteja, N.; Johri, A.K. Piriformospora indica rescues growth diminution of rice seedlings during high salt stress. Plant Signal. Behav. 2013, 8, e26891. [CrossRef] [PubMed]

56. Ghorbani, A.; Omran, V.O.G.; Razavi, S.M.; Pirdashti, H.; Ranjbar, M. Piriformospora indica confers salinity tolerance on tomato (Lycopersicon esculentum Mill.) through amelioration of nutrient accumulation, $\mathrm{K}+/ \mathrm{Na}+$ homeostasis and water status. Plant Cell Rep. 2019, 38, 1151-1163. [CrossRef]

57. Song, X.; Yue, X.; Chen, W.; Jiang, H.; Han, Y.; Li, X. Detection of Cadmium Risk to the Photosynthetic Performance of Hybrid Pennisetum. Front. Plant Sci. 2019, 10, 798. [CrossRef]

58. Morina, F.; Küpper, H. Direct inhibition of photosynthesis by $\mathrm{Cd}$ dominates over inhibition caused by micronutrient deficiency in the Cd/Zn hyperaccumulator Arabidopsis halleri. Plant Physiol. Biochem. 2020, 155, 252-261. [CrossRef]

59. Carrillo, J.T.; Borthakur, D. Methods for metal chelation in plant homeostasis: Review. Plant Physiol. Biochem. 2021, 163, 95-107. [CrossRef] [PubMed]

60. Xiao, Q.; Wang, Y.; Lü, Q.; Wen, H.; Han, B.; Chen, S.; Zheng, X.; Lin, R. Responses of glutathione and phytochelatins biosysthesis in a cadmium accumulator of Perilla frutescens (L.) Britt. under cadmium contaminated conditions. Ecotoxicol. Environ. Saf. 2020, 201, 110805. [CrossRef]

61. Lv, Y.; Deng, X.; Quan, L.; Xia, Y.; Shen, Z. Metallothioneins BcMT1 and BcMT2 from Brassica campestris enhance tolerance to cadmium and copper and decrease production of reactive oxygen species in Arabidopsis thaliana. Plant Soil 2012, 367, 507-519. [CrossRef]

62. Harada, E.; Yamaguchi, Y.; Koizumi, N.; Hiroshi, S. Cadmium stress induces production of thiol compounds and transcripts for enzymes involved in sulfur assimilation pathways in Arabidopsis. J. Plant Physiol. 2002, 159, 445-448. [CrossRef]

63. Kim, S.-J.; Shin, Y.H.; Kim, K.-H.; Park, E.-H.; Sa, J.-H.; Lim, C.-J. Regulation of the Gene Encoding Glutathione Synthetase from the Fission Yeast. J. Biochem. Mol. Biol. 2003, 36, 326-331. [CrossRef] [PubMed]

64. Estrella-Gómez, N.E.; Sauri-Duch, E.; Zapata-Perez, O.; Santamaría, J.M. Glutathione plays a role in protecting leaves of Salvinia minima from $\mathrm{Pb}^{2+}$ damage associated with changes in the expression of SmGS genes and increased activity of GS. Environ. Exp. Bot. 2012, 75, 188-194. [CrossRef]

65. Thomsen, H.C.; Eriksson, D.; Møller, I.S.; Schjoerring, J.K. Cytosolic glutamine synthetase: A target for improvement of crop nitrogen use efficiency? Trends Plant Sci. 2014, 19, 656-663. [CrossRef]

66. Martin, A.; Lee, J.; Kichey, T.; Gerentes, D.; Zivy, M.; Tatout, C.; Dubois, F.; Balliau, T.; Valot, B.; Davanture, M.; et al. Two Cytosolic Glutamine Synthetase Isoforms of Maize Are Specifically Involved in the Control of Grain Production. Plant Cell 2006, 18, 3252-3274. [CrossRef]

67. Habash, D.; Massiah, A.J.; Rong, H.L.; Wallsgrove, R.M.; A Leigh, R. The role of cytosolic glutamine synthetase in wheat. Ann. Appl. Biol. 2001, 138, 83-89. [CrossRef]

68. Hu, M.; Zhao, X.; Liu, Q.; Hong, X.; Zhang, W.; Zhang, Y.; Sun, L.; Li, H.; Tong, Y. Transgenic expression of plastidic glutamine synthetase increases nitrogen uptake and yield in wheat. Plant Biotechnol. J. 2018, 16, 1858-1867. [CrossRef]

69. Cai, H.; Zhou, Y.; Xiao, J.; Li, X.; Zhang, Q.; Lian, X. Overexpressed glutamine synthetase gene modifies nitrogen metabolism and abiotic stress responses in rice. Plant Cell Rep. 2009, 28, 527-537. [CrossRef]

70. Quastel, J.H.; Stewart, C.P.; Tunnicliffe, H.E. On glutathione. IV. Constitution. Biochem J. 1923, 17, 586-592. [CrossRef]

71. Ritz, D.; Beckwith, J. Roles of Thiol-Redox Pathways in Bacteria. Annu. Rev. Microbiol. 2001, 55, 21-48. [CrossRef] [PubMed]

72. Norambuena, J.; Wang, Y.; Hanson, T.; Boyd, J.; Barkay, T. Low-Molecular-Weight Thiols and Thioredoxins Are Important Players in $\mathrm{Hg}$ (II) Resistance in Thermus thermophilus HB27. Appl. Environ. Microbiol. 2018, 84, e01931-17. [CrossRef] [PubMed] 